甲状腺手術後のドレナージは必要か？

山際 幹和・徳力 俊治* ·藤田健一郎*

\title{
Discharge Quantity Drained after Thyroid Surgery
}

\author{
Mikikazu Yamagiwa \\ (Matsusaka Chuo Hospital)
}

Toshiharu Tokuriki and Ken-ichiro Fujita

(Mie University)

The need for drainage to prevent complications after thyroid surgery has been questioned by many authors since the late 1980s. However, little is known about the quantity of discharge after thyroid surgery.

We measured the amount of discharge drained continuously after hemithyroidectomy with or without contra-lateral tumor enucleation in 90 consecutive patients ( 10 males and 80 females, mean age 56 years, ranging in age from $24-79$ years) with benign (78 cases) and malignant (12 cases) thyroid tumors. The amount of drainage was not huge and ranged from 8 to $132 \mathrm{ml}$ with a mean of $51 \mathrm{ml}$ during the 4 days after surgery. The average amount was significantly larger in the patient group drained with a stronger suction system (J-VAC), when compared to that in the group with a weaker suction system (MANOVAC).

Where immediate action based on close observation of patients is available under life-threatening conditions, such as massive bleeding or airway obstruction, prophylactic routine drainage is not necessary after uncomplicated thyroid surgery.

Key words : discharge quantity, thyroid surgery, prophylactic drainage, postoperative complications

\section{はじめに}

1980年代中頃より, 欧米では合併症の無い例の甲状腺 手術後のドレナージは不要であるとする見解が涌出 (1) 7), 昨今ではとの外来手術すら試みられている899).

ドレナージ不要論者は, ドレナージ施行例と非施行例 の間で出血による再手術, 恒久的な反回神経麻㽻, 恒久 的な低カルシウム血症, 血腫, 創部の感染, リンパ漏な どの頻度を比較検討し，両者間で差がなかったことを主 たる根拠としているが，術後の排液量の経時的な測定成 績の報告は皆無に近い．
一部の著者によるドレナージ施行例で回収された血液 あるいは浸出液量に関する報告をみると，なかには 300 $\mathrm{ml}$ を越える例もあり2), 果たして, ドレナージは不要と 断言できるのかといら疑問も生じる.

そこで，われわれは甲状腺一側葉切除術と一側葉切除 十他側腫瘤核出術を施行した一連の患者で術後の排液量 を経時的に計測し，その測定成績が同様の範囲で手術を 施行した例での術後ドレナージの必要性の有無の判定資 料となることを期待して検討を加えた. 


\section{対象ならびに方法}

1993年 6 月より1996年 7 月の間に, 松阪中央総合病院 耳鼻咽喉科で甲状腺一側葉切除術 (75例) と一側葉切除+ 他側腫瘤核出術(15例)を行い, 吸引ドレナージによる排 液量を経時的に測定した 90 名(男性10名, 女性80名, 良 性腫瘍78例, 悪性腫瘍12例, 年龃24～79歳, 平均土標準 偏差56士12歳)を対象とした.

主たる手術操作は筆者のひとり (MY) が行い，もらひ とりが助手をつとめた.

手術時間は, 多くの例で迅速病理組織診断に要した時 間(20３0分)を含んでいるが，72１84分に分布し，そ の平均土標準偏差は117士27分であった. その間の出血 量は 14〜232 g に分布し, その平均土標準偏差は $64 \pm 38$ gであった.

使用したドレーンは吸引容量 $45 \mathrm{ml}$ の MANOVAC (ウェタッグ社, スイス)と同容量 $150 \mathrm{ml}$ の J-VAC (ジ ョンソン・エンド・ジョンソン メディカル社, 米国) で，前者を1995年 5 月までに手術した69例に，また，後 者をその後の21例に対して用いた。排液量の測定は毎日 午前 0 時に行った。

推計学的検討に際しては, MANOVACとJ-VACを 用いた患者の背景因子(性, 年齢, 術式, 病理組織型, 手術時間, 術中出血)に有意差がなかったので, 資料を ひとまとめにし，パラメトリックテスト（対応のない $\mathrm{t}$ 検定, Pearsonの相関係数)を用いて解析を行った.

\section{結 果}

1 ) 術後の排液量の推移(図 1 )

術直後(午後 $5 \sim 6$ 時頃) より同日深夜 ( 0 時) までの排 液量は 4〜 $50 \mathrm{ml}$ に分布し，その平均士標準偏差は $22 \pm$ $10 \mathrm{ml}$ (術後 0 日目), 翌日(術後 1 日目)の24時間のそれ らは 3〜 $52 \mathrm{ml}$ と $19 \pm 10 \mathrm{ml}(0+1$ 日の累積量の平均士 標準偏差 $42 \pm 18 \mathrm{ml}$ ), 術後 2 日目のそれらは 0〜19 ml と $5 \pm 4 \mathrm{ml}(0+1+2$ 日の累積量の平均土標準偏差 47 $\pm 20 \mathrm{ml})$, 術後 3 日目のそれらは $2 \pm 4 \mathrm{ml}(0+1+2$ +3 日の累積量の平均土標準偏差 $51 \pm 22 \mathrm{ml}$, 最大 132 $\mathrm{ml}$, 最小 $8 \mathrm{ml}$ ) で, 術後 2 日目の深夜までは全例にドレ ナージを行ったが，3 日目深夜までに53例(59\%)でド レーンを抜去した。

図 2 に示したよらに，術後 0 日目の排液量は 1 日目の それとかなり相関し (Pearsonの相関係数 $\mathrm{r}=0.559)$, 術 後 1 日目排液量 $(\mathrm{ml})=0.530 \times$ 術後 0 日目排液量 $(\mathrm{ml})+$

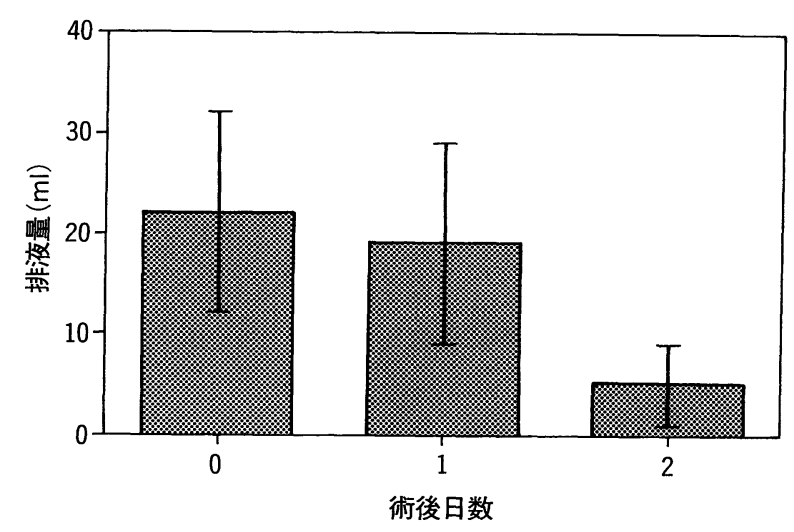

図 1 術後排液量 (平均土標準偏差)の推移 (甲状腺一側葉切除・一側葉切除 + 他側核出術施行 90 例)

7.575 の式が成立した。

しかしながら, 術後 0 日目の排液量は術後 2 日目以後 の排液量とは相関しなかった.

2 ) 術後 $0+1+2$ 日目の排液量に影響を及ぼす因子 術後 2 日目の深夜までの間の累積排液量に影響を及ぼ す因子の検討を行ったが, 患者の年齢, 病理組織型, 術 式, 手術時間, 術中出血量による排液量の差は認められ なかった。

性別にみると, 男性例(平均土標準偏差 $58 \pm 12 \mathrm{ml}$ ) は 女性例 (同 $46 \pm 20 \mathrm{ml}$ ) に比べその間の排液量が多い傾向 があったが，有意ではなかった $(P=0.0596)$.

使用したドレーン別にみると, J-VAC 使用例(平均士 標準偏差 $64 \pm 22 \mathrm{ml}$ ) は MANOVAC 使用例 (同 $42 \pm 16$ $\mathrm{ml})$ に比べその間の排液量が多く, 推計学的にも有意差 が認められた $(P<0.0001)$.

\section{考察}

甲状腺手術後のドレナージの目的は，言うまでもなく， 創部から血液や浸出液を排除し, 時には致死的となる術 後の合併症を予防することにある.

多くの筆者が述べているように，ドレナージ施行例と 非施行例の間で出血による再手術, 恒久的な反回神経麻 痺, 恒久的な低カルシウム血症, 血腫, 創部の感染, リ ソパ漏などの頻度に差がなく1) 7)，今回のわれわれの検 討結果からも, 術後の累積排液量は平均 $51 \mathrm{ml}$ で最大で も $132 \mathrm{ml}$ であったことから,一般論としては, ドレナー ジは必要がないと結論できそうである。

また，ドレナージの短所として， 


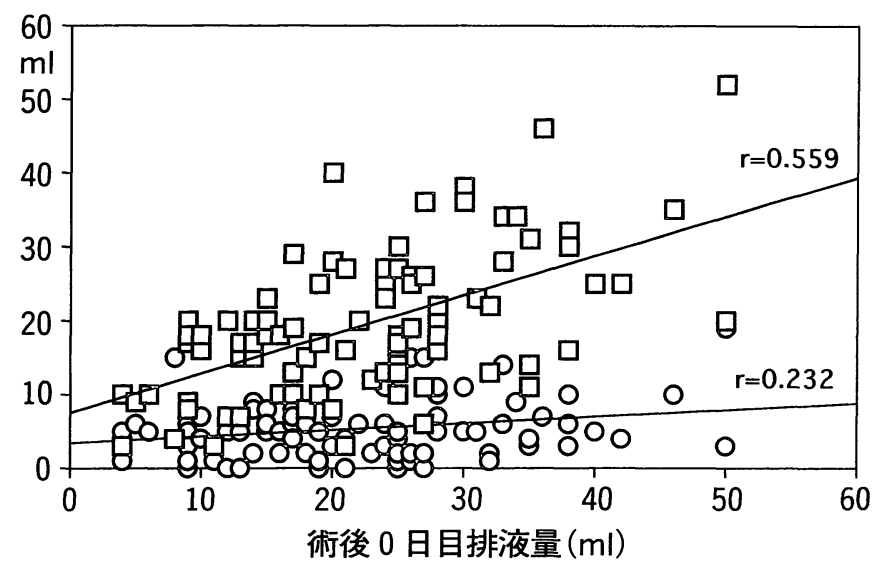

$\square:$ 術後 1 日目排液量 $(\mathrm{ml})=0.530 \times$ 術後 0 日目排液量 $(\mathrm{ml})+7.575$

$\mathrm{O}:$ 術後 2 日目排液量 $(\mathrm{ml})$

図 2 術後 0 日目排夜量と術後 1,2 日目排夜量の相関 (甲状腺一側葉切除・一側葉切除+他側核出術施行90例)

1）患者の不快感を増長する

2 ) 不経済 (材料費増加，入院期間の延長)

3 ）瘶痕形成

4 ）信頼性に疑問がある(塞栓の形成)

5 ）組織液の排出を助長する,などが指摘されてい

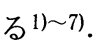

このよらな点をみると，ますますドレナージは不要で あるととらえられがちになるが，それを行らか否かを最 終的に決定するらえでは，さらにいくつかの点を合わせ て検討する必要がある．もちろん，術後早期に生じる合 併症の中で最も問題となるのは，頻度が極めて低いとは 言え，大量失血や窒息などの致死的状態を引き起こす大 出血である.ドレーンを創部に留置する大きな目的のひ とつは，その監視と早期検知である。したがって，医師 や看護婦が十分頻回に巡回し創部の点検ができ，そのよ らな緊急事態に対処できるよらな体制下ではドレナージ の必要性は低くなる，そうでない条件下，例えば，当院 のよらな施設では，ドレナージの持つ出血監視の働きは 加療者に安心感を与えるらえでも少なからず効果を発揮 する.

ドレナージを施行しなかった患者で術後合併症が生じ， かつ，それが法的な問題を引き起こしたような場合，ド レナージの有無が論争点となる可能性はある。ちなみに, アメリカ外科医師会・術前術後管理委員会編「術前術後 の管理マニュアル」には甲状腺手術の汪とんどの例に対
して小さな吸引カテーテルを出血と血腫に対処する目的 で用いることが合理的であることが記載されて扣り10), 現時点でもドレナージ必要論者の比率は高いものと推察 される。

術後ドレナージが必要であるか否かを, 術中に予知で きれば申し分ない，われわれの検討では，わずかに男性 患者では術後排液量が多くなる可能性が示唆されたのみ である。

興味深い点は, 吸引力が強い J-VACでドレナージを 行った際の累積排液量がそれの弱いMANOVACを用 いた際の累積排液量より有意に多かった点である．腹部 外科領域では，吸引ドレナージが組織に陰圧を加えるこ とから排液量を増加させる可能性があることが報告され ている11)12)。これは傾聴すべき見解であり, 頸部領域で も吸引力の強いドレナージほど排液量を増加させる可能 性がある.したがって，ドレナージを行らに際しては， 毛細管現象を利用した静的ドレナージをも視野に入れた ドレーンの選択も重要課題になる.

$$
\text { まとめ }
$$

甲状腺一側葉切除術之一側葉切除十他側腫瘤核出術を 行った一連の患者 90 名を対象にして術後排液量を経時的 に計測したところ, 術後 3 日目までの累積排液量の平均

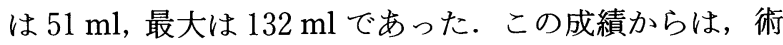
後合併症の監視体制が整った施設では術後のドレナージ 
は不要と結論できる.

そのような体制がない施設では, 致死的大量術後出血 を早期に検知する意味で術後 2 日目までのドレナージが

望ましいと考える。

本論文の要旨は第 58 回耳鼻咽喉科臨床学会学術講演会 (名古 屋市，1996年 6 月 28，29日)において演述した。

\section{参考文献}

1) Kristoffersson A, Sandzen B and Jaerhult J : Drainage in uncomplicated thyroid and parathyroid surgery. $\mathrm{Br} J$ Surg $73: 121 \sim 122,1986$.

2 ) Wihlborg O, Bergljung L and Maartensson H : To drain or not to drain in thyroid surgery. Arch Surg $123: 40 \sim 41$, 1988.

3 ) Ayyash K, Khammash M and Tibblin S : Drain vs. no drain in primary thyroid and parathyroid surgery. Eur $\mathrm{J}$ Surg $157:$ 113 114, 1991.

4) Ruark DS and Adbel-Misih RZ : Thyroid and parathyroid surgery without drains. Head Neck $14: 285 \sim 287,1992$.

5 ) Peix JL, Teboul F, Feldman H, et al : Drainage after thyroidectomy : A randomized clinical trial. Int Surg $77: 122 \sim 124,1992$.
6 ) Shaha AR and Jaffe BM : Selective use of drains in thyroid surgery. J Surg Oncol 52 : 241 243, 1993.

7 ) Wax MK, Valiulis AP and Hurst MK : Drains in thyroid and parathyroid surgery. Arch Otolaryngol Head Neck Surg $121:$ 981 983, 1995.

8 ) LoGerfo P, Gates R and Gazetas P : Outpatient and shortstay thyroid surgery. Head Neck $13: 97 \sim 101,1991$.

9 ) Mishra SK, Sharma AK and Thakur S: Outpatient and short-stay thyroid surgery. Head Neck $14: 247 \sim 248,1992$.

10) アメリカ外科医師会・術前術後管理委員会編 (大塚俊通 監訳）: 甲状腺の外科. 術前術後の管理マニュアル 第 3 版. 502 523頁, 西村書店, 新潟, 1992.

11) Goldberg IM, Goldberg JP, Liechty RD, et al : Cholecystectomy with and without surgical drainage. Am J Surg $130: 29 \sim 32,1975$.

12) Lewis RT, Goodall RG, Marien B, et al : Simple elective cholecystectomy : To drain or not. Am J Surg $159: 241 \sim$ 245,1990 .

$$
\left(\begin{array}{l}
\text { 原稿受付: 平成 } 8 \text { 年 } 10 \text { 月 } 25 \text { 日 } \\
\text { 原稿採択 : 平成 } 8 \text { 年 } 12 \text { 月 } 4 \text { 日 } \\
\text { 別刷請求先 : 山際幹和 } \\
\text { † } 515 \text { 松阪市鎌田町 } 145 \\
\text { 松阪中央総合病院耳鼻咽喉科 }
\end{array}\right)
$$

